JURNAL BASICEDU

Research \& Learning in Elementary Education

https://jbasic.org/index.php/basicedu

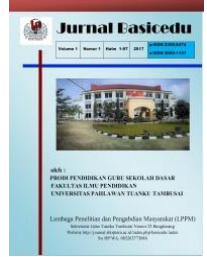

\title{
PENGARUH PENDEKATAN REALISTIC MATHEMATICS EDUCATION (RME) DAN SELF EFFICACY TERHADAP KEMAMPUAN PEMECAHAN MASALAH MATEMATIS SISWA DI SEKOLAH DASAR
}

\author{
Oktaveni Yetri ${ }^{1}$, Ahmad Fauzan ${ }^{2}$, Desyandri ${ }^{3}$, Yanti Fitria ${ }^{4}$, dan Farida Fahrudin ${ }^{5}$ \\ Universitas Negeri Padang, Sumatera Barat, Indonesia ${ }^{1,2,3,4,5}$ \\ Email : oktaveni27@yahoo.com ${ }^{1}$, ahmad.zan66@ gmail.com ${ }^{2}$, desyandri@fip.unp.ac.id ${ }^{3}$, yanti_fitria@ fip.unp.ac.id ${ }^{4}$, \\ faridafahrudin6@gmail.com ${ }^{5}$
}

\begin{abstract}
Abstrak
Artikel ini dilatarbelakangi oleh rendahnya kemampuan pemecahan masalah siswa kelas IV SD. Hal ini terjadi karena siswa secara langsung menyelesaikan masalah yang diberikan oleh guru. Masalah yang diberikan oleh guru belum berbentuk abstrak sehingga siswa kurang memahami masalah yang diberikan. Salah satu upaya yang dapat dilakukan untuk mengatasi permasalahan tersebut adalah dengan pendekatan realistic mathematics education. Jenis penelitian ini adalah quasi experiment. Populasi pada penelitian ini adalah siswa kelas IV SD Negeri 22 Andalas Padang Tahun Pelajaran 2018/2019. Sampel penelitian ini yaitu siswa kelas IV.b sebagai kelas eksperimen dan siswa Kelas IV.c sebagai kelas kontrol. Data penelitian diperoleh dari hasil tes kemampuan pemecahan masalah matematis siswa serta angket self efficacy. Analisis data dilakukan menggunakan uji Anava dua arah. Berdasarkan hasil analisis data dan pembahasan diperoleh bahwa terdapat perbedaan kemampuan pemecahan masalah matematis siswa yang diajarkan menggunakan pendekatan Realistic Mathematics Education (RME) dengan pendekatan konvensional pada siswa kelas IV SD 22 Andalas Padang dengan $\mathrm{F}_{\text {hitung }}>\mathrm{F}_{\text {tabel }}$. Kemampuan pemecahan masalah matematis siswa yang memiliki self efficacy tinggi tidak memiliki perbedaan dengan kemampuan pemecahan masalah matematis siswa yang memiliki self efficacy rendah dengan $F_{\text {hitung }}<\mathrm{F}_{\text {tabel }}$. Self efficacy, pendekatan Realistic Mathematics Education (RME) dan pendekatan konvensional tidak memiliki interaksi dalam mempengaruhi kemampuan pemecahan masalah matematis siswa dengan $\mathrm{F}_{\text {hitung }}<\mathrm{F}_{\text {tabel }}$. Selain itu, self efficacy memiliki hubungan dengan kemampuan pemecahan masalah matematis siswa dengan $t_{\text {hitung }}>\mathrm{t}_{\text {tabel. }}$.
\end{abstract}

Kata Kunci: RME, Self Efficacy, Kemampuan Pemecahan Masalah

\begin{abstract}
Abstrack
This article is motivated by the low problem solving ability of fourth grade elementary school students. This happens because students solve problems given by the teacher. The problem given by the teacher has not formed an Abstract so students are less able to solve the given problem. One effort that can be done to overcome these problems is a realistic mathematics education. This type of research is a quasi experiment. The population in this study was the fourth grade students of SD Negeri 22 Andalas Padang in the 2018/2019 academic year. The sample of this research is students in class IV.b as the experimental class and students in Class IV.c as the control class. The research data were obtained from the test results of students' mathematical problem solving abilities and self efficacy questionnaires. Data analysis was performed using the two-way Anava test. Based on the results of data analysis and discussion, it was found that there were differences in students' mathematical problem solving abilities that were taught using the Realistic Mathematics Education (RME) approach with the conventional approach to class IV students at SD 22 Andalas Padang with $\mathrm{F}_{\text {count }}>\mathrm{F}_{\text {table }}$. Mathematical problem solving ability of students who have high self efficacy has no difference with the mathematical problem solving ability of students who have low self efficacy with $\mathrm{F}_{\text {count }}<\mathrm{F}_{\text {table }}$. Self efficacy, Realistic Mathematics Education (RME) approaches and conventional approaches have no interaction in influencing students' mathematical problem solving abilities with $\mathrm{F}_{\text {count }}<\mathrm{F}_{\text {table }}$. In addition, self efficacy has a relationship with students' mathematical problem solving abilities with $t_{\text {count }}>t_{\text {table. }}$.
\end{abstract}

Keywords: RME, Self Efficacy, Problem Solving Ability

@ Jurnal Basicedu Prodi PGSD FIP UPTT 2019

$\triangle$ Corresponding author :

Address :

Email

ISSN 2580-3735 (Media Cetak)

Phone

\author{
ISSN 2580-1147 (Media Online)
}




\section{PENDAHULUAN}

Salah satu usaha untuk meningkatkan kualitas pendidikan adalah dengan meningkatkan pendidikan. Salah satunya pendidikan pada pembelajaran matematika. Hal penting dalam pembelajaran matematika adalah kemampuan siswa dalam pemecahan masalah matematika. Kemampuan pemecahan masalah merupakan konsep dasar yang harus dimiliki siswa dalam pembelajaran matematika, aktivitas pembelajaran tidak hanya difokuskan pada upaya mendapatkan pengetahuan sebanyak-banyaknya, melainkan jugacaramenggunakan segenap pengetahuan yang didapat untuk menghadapi situasi baru atau memecahkan masalah-masalah khusus. Pemecahan masalah yang sumber masalahnya berasal dari kehidupan sehari-hari siswa akan membentuk pemahaman siswa dalam pembelajaran matematika.

Pada kenyataannya, dalam tes Program for International Student Assessment (PISA) negara Indonesia masih berada pada level yang paling bawah. Menurut Setyaningsih (2015:6) hasil terbaru dari PISA 2009 semakin melengkapi rendahnya kemampuan siswa-siswa Indonesia dibandingkan dengan negara-negara lain. Semakin jelas bahwa kemampuan siswa Indonesia dalam menyelesaikan soal-soal yang menuntut kemampuan untuk menelaah, memberi alasan dan mengomunikasikannya secara efektif, serta memecahkan dan menginterpretasikan permasalahan dalam berbagai situasi masih sangat kurang. Dari 65 negara peserta PISA 2009, Indonesia menempati posisi ke 61 untuk PISA Matematika. Menurut data PISA di atas siswa Indonesia dikategorikan pada tingkat 2, yang hanya mampumenafsirkan atau mengenali situasidalam konteks soal yang diberikan, dan mengerjakan soal menggunakan rumus-rumus umum atau secara algoritmik, sehinggadapat diasumsikansiswa belum mampu mengembangkan kemampuan berpikir tingkat tingginya.

Berdasarkan observasi awal pembelajaran di kelas IV SD Negeri 22 Andalas Padang didapat bahwa siswa masih kesulitan dalam memecahkan masalah matematika, permasalahan yang dihadapi siswa adalah merasa tidak yakin akan kemampuannya untuk mampu memecahkan masalah yang sedang mereka hadapi. Salah satu penyebabnya karena mereka sering merasa tidak yakin bahwa dirinya akan mampu menyelesaikan tugas-tugas yang dibebankan padanya. Dalam proses pembelajaran para siswa beranggapan bahwa matematika itu menakutkan. Pembelajaran matematika membuat siswa merasa takut karena siswa tidak bisa mengerjakan soal yang diberikan, takut salah dalam mengerjakan, takut untuk bertanya materi yang tidak siswa pahami sehingga siswa merasa tambah sulit dan tambah malas mengerjakannya, dan tidak percaya diri.

Permasalahan-permasalahan siswa diatas dapat teratasi apabila siswa memiliki keyakinan diri akan kemampuan yang dimilikinya dalam menyelesaikan suatu persoalan matematika yang harus diselesaikan. Bagi pelajar, keyakinan sangat diperlukan. Keyakinan akan mengarahkan kepada pemilihan tindakan, pengerahan usaha, serta keuletan. Keyakinan yang didasari oleh batas-batas kemampuan yang dirasakan akan menuntun pelajar berprilaku secara mantap dan efektif. Keyakinan diri tersebut oleh Bandura disebut self-efficacy. Keyakinan tersebut mendorong siswa untuk mencapai keberhasilan. Karena dengan keyakinan tinggi mereka akan berupaya sekuat tenaga untuk mencapai tujuan yaitu prestasi belajar. (Rosyida, Fatiya; Utaya, 2016:91)

Pembelajaran dengan pendekatan konvensional membuat siswa cenderung malas dan bosan untuk belajar sehingga konsep-konsep tentang pokok bahasan tersebut belum benar-benar dikuasai siswa. Untuk itu diperlukan suatu 
pendekatan pembelajaran yang dapat mendorong siswa aktif, sehingga siswa dapat memahami konsep-konsep tentang pokok bahasan yang diajarkan guru dengan baik. Maka dapat diajukan alternative tindakan dengan pendekatan pembelajaran Realistic Mathematics Education (RME).

Pendekatan pembelajaran Realistic Mathematics Education (RME) menurut Gunawan (dalam Fitriani \& Maulana, 2016:42) menyebutkan bahwa RME adalah suatu teori pembelajaran matematika yang beranggapan bahwa matematika adalah aktivitas manusia serta matematika harus dihubungkan terhadap konteks kehidupan seharihari. Senada dengan Freudenthal (dalam Djam'an, 2014:17) menyatakan bahwa: Indeed, the basic idea behind the RME is that mathematics must be connected to reality and mathematics be seen as a human activity. Mathematics must be close to children, and be relevant to everyday life situations. Ide dasar dibalik RME adalah bahwa matematika harus terhubung dengan realitas dan matematika dipandang sebagai aktivitas manusia. Matematika harus dekat dengan anak-anak, dan relevan dengan situasi kehidupan sehari-hari.

Menurut Fauzan \& Sari (2017:B55) gagasan utama RME adalah anak-anak harus diberikan kesempatan untuk menemukan kembali matematika di bawah bimbingan orang dewasa (guru). Itu berarti bahwa dengan melakukan beberapa kegiatan pemecahan kontekstual masalah yang nyata bagi siswa, mereka dapat menggunakan pengetahuan informal mereka untuk menemukan kembali matematika.

Pendekatan ini memiliki keunggulan antara lain pembelajaran menjadi cukup menyenangkan dan tidak tampak menegangkan bagi siswa, materi dapat dipahami sebagian besar oleh siswa karena RME diawali dengan menggunakan masalah kontekstual sehingga memungkinkan siswa menggunakan pengalaman sebelumnya dan pengetahuan awal yang dimiliki secara langsung, pembelajaran mengarahkan siswa untuk dapat memecahkan masalah secara informal sesuai dengan pengalaman mereka dan dapat melatih siswa untuk dapat menyampaikan pendapat. Berdasarkan masalah sebagaimana telah diuraikan di atas maka peneliti memandang penting, dan perlu melakukan penelitian untuk melihat pengaruh Pendekatan Realistic Mathematics Education (RME) dan self efficacy siswa terhadap kemampuan pemecahan masalah matematis siswa kelas IV SD.

\section{METODE}

Penelitian ini menggunakan pendekatan kuantitatif dalam bentuk Quasi Eksprimental Design. Sesuai dengan desain penelitian maka penelitian menggunakan dua kelas yaitu kelas eksperimen adalah kelas yang sengaja diberi perlakuan Pendekatan Realistic Mathematics Education (RME), dan kelas kontrol menggunakan pendekatan konvensional. Variabel dalam penelitian ini terdiri dari (1) variabel bebas yaitu Pendekatan Realistic Mathematics Education (RME), (2) variabel modetor yaitu self efficacy, (3) variabel terikat yaitu kemampuan pemecahan masalah.

Populasi pada penelitian ini adalah kelas IV SD 22 Andalas Padang Tahun Ajaran 2018/2019. Sementara itu, hasil pengambilan sampel secara acak diperoleh kelas IV.B sebagai kelas eksperimen (pendekatan Realistic Mathematics Education (RME)) dan kelas IV.C sebagai kelas kontrol (pendekatan konvensional). Penelitian dilaksanakan pada tanggal 20 November 2018 dengan mengikuti jadwal yang sudah ditentukan oleh sekolah pada materi pecahan dengan Kompetensi Dasar (KD) 3.7 Menjelaskan dan melakukan pembulatan hasil pengukuran panjang dan berat ke satuan terdekat dan 4.7 
Menyelesaikan masalah pembulatan hasil pengukuran panjang dan berat ke satuan terdekat.

Rancangan atau desain eksperimen yang digunakan pada penelitian ini adalah factorial design, yaitu dengan memperhatikan adanya variabel moderator yang mempengaruhi perlakuan variabel independen terhadap hasil variabel dependen (desain faktorial $2 \times 2$ ), (Yusuf, 2013:191). Rancangan atau desain penelitian ini dapat digambarkan seperti tabel berikut:

Tabel 1. Rancangan Penelitian Factorial Design

\begin{tabular}{|c|l|c|c|}
\hline \multicolumn{2}{|c|}{} & \multicolumn{2}{c|}{ Pendekatan } \\
\cline { 3 - 4 } \multicolumn{2}{|c|}{} & RME & $\begin{array}{c}\text { Konvensiona } \\
1\left(\mathrm{~A}_{2}\right)\end{array}$ \\
\hline \multirow{2}{*}{$\begin{array}{c}\text { Self } \\
\text { efficacy }\end{array}$} & Tinggi & A & B \\
\cline { 2 - 4 } & Rendah & C & D \\
\hline
\end{tabular}

Keterangan:

A : Kemampuan pemecahan masalah matematis siswa dengan self efficacy tinggi pada kelas eksperimen (diajar dengan Pendekatan RME)

B : Kemampuan pemecahan masalah matematis siswa dengan self efficacy tinggi pada kelas kontrol (diajar dengan pendekatan konvensional)

C : Kemampuan pemecahan masalah matematis siswa dengan self efficacy rendah pada kelas eksperimen (diajar dengan Pendekatan RME)

D : Kemampuan pemecahan masalah matematis siswa dengan self efficacy rendah pada kelas kontrol (diajar dengan pendekatan konvensional)

Instrumen penelitian terbagi menjadi dua jenis, yakni instrument pembelajaran dan instrument pengumpulan data. Pada instrument pembelajaran, peneliti menyediakan RPP dan LKS. Sementara itu, peneliti menggunakan angket dan lembar soal kemampuan pemecahan masalah. Dalam hal ini, instrument pengumpulan data dilakukan uji coba dan pengolahan data terlebih dahulu.
Data yang diperoleh dalam penelitian ini, selanjutnya dilakukan analisis melalui uji hipotesis. Uji hiposis dilakukan dengan prasyarat, yakni uji normalitas dan uji homogenitas. Uji normalitas data dilakukan dengan menggunakan uji Lilliefors, sedangkan uji homogenitas variansi dilakukan dengan uji $F$ pada taraf signifikansi $\alpha$ $(0,05)$. Uji hipotesis dilakukan dengan menggunakan uji Anova Dua Arah dan uji korelasi produk moment.

\section{HASIL DAN PEMBAHASAN}

Penelitian ini telah mengungkapkan bahwa pendekatan realistic mathematics education memberikan pengaruh yang positif terhadap kemampuan pemecahan masalah matematis. Penerapan pendekatan realistic mathematics education dalam pembelajaran matematika secara nyata dapat mengembangkan ide dan konsep siswa dalam mengembangkan kemampuan pemecahan masalah matematis. Siswa mampu menyelesaikan masalah dengan sendiri dan berkelompok karena masalah yang diberikan nyata dan siswa terlibat langsung dalam memecahkan permasalahan yang diberikan dan bekerjasama dalam kerja kelompok. Hal ini terlihat dari rerata skor kemampuan pemecahan masalah matematis kelas eksperimen yaitu 27,78, rerata skor kemampuan pemecahan masalah matematis kelas kontrol yaitu 24,5 sedangkan skor tertinggi kelas eksperimen yaitu 37 , dan skor terendah 15 , dan skor tertinggi kelas kontrol yaitu 36 dan skor terendah 12 .

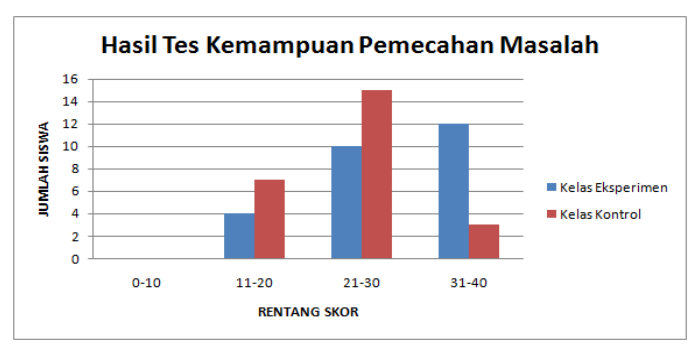

Gambar 1. Diagram Batang Hasil Tes Kemampuan pemecahan masalah matematis Siswa Pada Kelas Eksperimen dan Kontrol 
Pelaksanaan pendekatan realistic mathematics education berhasil mempengaruhi kemampuan pemecahan masalah matematis siswa. Hal ini dapat dilihat dari hasil tes kemampuan pemecahan masalah matematis siswa yang mendapat perlakuan dengan pendekatan realistic mathematics education menunjukkan peningkatan secara signifikan dibandingkan dengan siswa yang tidak mendapatkan perlakuan. Hal ini diperoleh oleh siswa karena sebelumnya telah melaksanakan pembelajaran dengan pendekatan realistic mathematics education. Salah satu karakteristik mendasar dalam RME yang diperkenalkan oleh Frudenthal adalah guided reinvention sebagai suatu proses yang dilakukan siswa secara aktif untuk menemukan kembali suatu konsep matematika dengan bimbingan guru (Fauzan, 2013:12). Oleh karena itu, keunggulan pendekatan realistic mathematics education dapat ditemui dan bermanfaat dalam proses pembelajaran.

\section{Menurut (Pangastuti,}

mengemukakan bahwa pendekatan realistic mathematics education memberikan kesempatan Siswa membangun sendiri pengetahuan, sehingga siswa tidak mudahlupa dengan pengetahuannya dan suasana proses pembelajaran menyenangkan karena menggunakan realitas kehidupan, sehingga siswa tidak cepat bosan belajar matematika

$$
\text { Keunggulan pendekatan realistic }
$$
mathematics education dibandingkan pendekatan konvensional adalah bahwa pendekatan realistic mathematics education adalah masalah dijelaskan dengan cara yang memungkinkan siswa untuk mengatasinya. Selain itu dengan membuat skematisasi dan mengidentifikasi hubungan pusat dalam situasi masalah, murid akan memahami masalah dengan lebih baik. Deskripsi juga diberikan untuk menyederhanakan masalah dengan menggambarkan hubungan dan membedakan halhal penting besar dan kecil.
Pada pendekatan realistic mathematics education siswa yang belajar secara berkelompok mempunyai tanggung jawab untuk memecahkan permasalahan dan mempresentasikan hasil diskusi serta membandingkan dengan kelompok lain sekaligus menanggapi dan menyampaikan pendapat terdapat penampilan kelompok lain sehingga semua siswa dapat melihat cara penyelesaian permasalahan antar kelompok.

Berbeda dengan pendekatan realistic mathematics education, pendekatan konvensional menempatkan siswa sebagai objek belajar yang berperan sebagai penerima informasi secara pasif. Pada umumnya, penyampaian pembelajaran menggunakan metode ceramah, tanya jawab, dan penugasan. Guru selalu mendominasi kegiatan pembelajaran, sedangkan siswa lebih banyak menerima dari guru. Hal ini sesuai dengan pendapat Nasution (2002:209) yang menyatakan bahwa metode belajar konvensional merupakan metode yang pengalaman belajar berorientasi kepada guru. Partisipasi siswa kebanyakan bersifat pasif. Siswa yang diajar dengan pendekatan konvensional cenderung tidak percaya diri, sedikit mempunyai self efficacy, informasi berasal dari guru, tidak belajar mandiri dan menyelesaikan masalah dengan ide mereka sendiri.

Pada pembelajaran konvensional, siswa belum mampu mengembangkan kemampuan pemecahan masalah masalah matematis. Hal ini dimungkinkan karena siswa menerima materi dan menyelesaikan masalah sesuai dengan yang diberikan oleh guru dalam pembelajaran. Kemudian mencatat hasil penjelasan guru dan contoh soal yang diberikan. Dalam pelaksanaan pembelajaran guru sedikit memberikan kesempatan kepada siswa untuk menyelesaikan masalah dengan ide-ide mereka. Sehingga kemampuan pemecahan masalah matematis siswa tidak terlihat dalam menyelesaikan permasalahan yang ada. Peran guru dalam pembelajaran 
konvensional yang sangat dominan mengakibatkan siswa kurang berperan aktif dan lebih banyak mendengarkan penjelasan dari guru daripada menemukan ide-ide.

Berdasarkan uraian di atas, dari hasil temuan penelitian dan analisis data yang telah dilakukan dapat disimpulkan bahwa pendekatan realistic mathematics education memberikan pengaruh terhadap kemampuan pemecahan masalah matematis siswa. Selain itu, hasil penelitian dengan pendekatan realistic mathematics education ini juga memperkuat hasil penelitian yang pernah dilakukan oleh peneliti sebelumnya tentang pendekatan realistic mathematics education seperti penelitian yang dilakukan oleh Susanti (2017), melakukan penelitian dengan judul "Meningkatkan Kemampuan Pemecahan Masalah Matematis dan Self-Efficacy Siswa MTs Melalui Pendekatan Pendidikan Matematika Realistik". Hasil penelitian menunjukkan bahwa pembelajaran dengan menggunakan pendekatan RME memiliki pengaruh terhadap kemampuan pemecahan masalah matematis siswa. Hal ini diketahui dan diperoleh dengan adanya perbedaan rata-rata skor gain kemampuan pemecahan masalah matematis yang diperoleh siswa pada kelas eksperimen dan kelas kontrol setelah proses pembelajaran. Ratarata skor gain self-efficacy siswa terhadap matematika kelas eksperimen $(0,518)$ lebih tinggi dibandingkan dengan rata-rata skor gain selfefficacy siswa terhadap matematika kelas kontrol $(0,166)$. Selain itu, uji hipotesis diperoleh $\mathrm{F}_{\text {hitung }}=$ 7,51 sehingga $F_{\text {hitung }}>F_{\text {tabel }}$ sehingga dapat diambil kesimpulan $\mathrm{H}_{0}$ ditolak dan $\mathrm{H}_{1}$ diterima. Artinya, terdapat perbedaan kemampuan pemecahan masalah matematis siswa yang diajarkan menggunakan pendekatan Realistic Mathematics Education (RME) dengan pendekatan konvensional pada siswa kelas IV SD 22 Andalas Padang.
Pada pengujian hipotesis kedua diperoleh bahwa kemampuan pemecahan masalah matematis siswa yang memiliki self efficacy tinggi dan siswa yang memiliki self efficacy rendah yang diajar dengan pendekatan realistic mathematics education terhadap tidak terdapat perbedaan diantara keduanya. Hal ini dapat dilihat dari perbedaan reratanya. Rerata skor tes akhir kemampuan pemecahan masalah matematis siswa dengan self efficacy tinggi adalah 28,0 sedangkan Rerata skor tes akhir kemampuan pemecahan masalah matematis siswa dengan self efficacy rendah sebesar 23,45. Kemudian, hasil uji Anova Dua Arah diperoleh $\mathrm{F}_{\text {hitung }}=3,15$ sehingga $F_{\text {hitung }}<F_{\text {tabel }}$ sehingga dapat diambil kesimpulan $\mathrm{H}_{0}$ diterima dan $\mathrm{H}_{1}$ ditolak.

Kemampuan pemecahan masalah siswa dengan self efficacy sebagai evaluasi seseorang mengenai kemampuan atau kompetensi dirinya untuk melakukan suatu tugas, mencapai suatu tujuan, dan mengatasi hambatan. Self efficacy mengacu pada keyakinan individu mengenai kemampuan untuk memobilisasi motivasi, sumber daya kognitif, dan tindakan yang diperlukan agar mencapai keberhasilan dalam melaksanakan tugas yang diberikan. self efficacy nerujuk kepada keyakinan yang dimiliki oleh individu atau pebelajar untuk dapat menyelesaikan suatu tugas spesifik tertentu dan keyakinan mengenai hasil yang akan diperolehnya nanti.

Siswa dengan self efficacy tinggi dalam mengerjakan suatu tugas, individu akan cenderung memilih terlibat langsung sekalipun tugas tersebut adalah tugas yang sulit. Mereka tidak memandang tugas sebagai suatu ancaman yang harus mereka hindari. Selain itu, mereka mengembangkan minat instrinsik dan ketertarikan yang mendalam terhadap suatu aktivitas, mengembangkan tujuan, dan berkomitmen dalam mencapai tujuan tersebut. Mereka juga meningkatkan usaha mereka dalam mencegah kegagalan yang mungkin timbul. 
Mereka yang gagal dalam melaksanakan sesuatu, biasanya cepat mendapatkan kembali self-efficacy mereka setelah mengalami kegagalan tersebut.

Siswa self efficacy rendah akan menjauhi tugas-tugas yang sulit karena tugas tersebut dipandang sebagai ancaman bagi mereka. Individu yang seperti ini memiliki aspirasi yang rendah serta komitmen yang rendah dalam mencapai tujuan yang mereka pilih atau mereka tetapkan. Ketika menghadapi tugas-tugas yang sulit, mereka sibuk memikirkan kekurangan-kekurangan diri mereka, gangguan-gangguan yang mereka hadapi, dan semua hasil yang dapat merugikan mereka. Individu yang memiliki self-efficacy yang rendah tidak berfikir tentang bagaimana cara yang baik dalam menghadapi tugas-tugas yang sulit. Saat menghadapi tugas yang sulit, mereka juga lamban dalam membenahi atau pun mendapatkan kembali self-efficacy mereka ketika menghadapi kegagalan. Didalam melaksanakan berbagai tugas, mereka yang memiliki self-efficacy rendah mencobapun tidak bisa, tidak peduli betapa baiknya kemampuan mereka yang sesungguhnya. Rasa percaya diri meningkatkan hasrat untuk berprestasi, sedangkan keraguan menurunkannya.

Ada beberapa faktor yang dapat ditemukan untuk mengetahui rendah atau tingginya self efficacy seorang siswa. Pertama adalah budaya, budaya mempengaruhi self efficacy melalui nilai (values), kepercayaan (beliefs), dalam proses pengaturan diri (self-regulatory process) yang berfungsi sebagai sumber penilaian self efficacy dan juga sebagai konsekuensi dari keyakinan akan self efficacy. Kedua adalah Gender, Perbedaan gender juga berpengaruh terhadap self efficacy. Hal ini dapat dilihat dari penelitian Bandura yang menyatakan bahwa wanita efikasinya lebih tinggi dalam mengelola perannya.. Ketiga adalah sifat dari tugas yang dihadapi, derajat dari kompleksitas dari kesulitan tugas yang dihadapi oleh individu akan mempengaruhi penilaian individu tersebut terhadap kemampuan dirinya sendiri. Semakin kompleks tugas yang dihadapi oleh individu maka akan semakin rendah individu tersebut menilai kemampuanya. Sebaliknya, jika individu dihadapkan pada tugas yang mudah dan sederhana maka akan semakin tinggi individu tersebut menilai kemampuanya. Keempat adalah intensif eksternal, yaitu insentif yang diberikan orang lain yang merefleksikan keberhasilan seseorang. Kelima adalah status atau peran individu dalam lingkungan, Individu yang memiliki status yang lebih tinggi akan memperoleh derajat kontrol yang lebih besar sehingga self-efficacy yang dimilikinya juga tinggi. Sedangkan individu yang memiliki status yang lebih rendah akan memiliki kontrol yang lebih kecil sehingga self-efficacy yang dimilikinya juga rendah. Keenam yaitu informasi tentang kemampuan diri, Individu yang memiliki self-efficacy tinggi, jika ia memperoleh informasi positif mengenai dirinya, sementara individu akan memiliki self efficacy yang rendah, jika ia memperoleh informasi negatif mengenai dirinya.

Berdasarkan uraian di atas, dapat disimpulkan bahwa siswa yang memiliki self efficacy tinggi dan siswa yang memiliki self efficacy rendah ditentukan oleh faktor-faktor di atas.

Pada pengujian hipotesis, tidak terdapat interaksi antara self efficacy dengan pendekatan realistic mathematics education terhadap kemampuan pemecahan masalah matematis. Artinya siswa yang diajar dengan pendekatan realistic mathematics education dan konvensional dengan self efficacy tidak saling berpengaruh terhadap kemampuan pemecahan masalah matematis siswa. Hal ini menunjukkan bahwa self efficacy tidak bergantung pada pendekatanpembelajaran yang dilaksanakan maupun sebaliknya dalam mempengaruhi kemampuan pemecahan masalah matematis siswa. Hal ini ditemukan dari hasil uji anova dua arah 
yang memperoleh $\mathrm{F}_{\text {hitung }}=0,76$ sedangkan $\mathrm{F}_{\text {hitung }}<\mathrm{F}_{\text {tabel}}$, sehingga dapat diambil kesimpulan $\mathrm{H}_{0}$ diterima dan $\mathrm{H}_{1}$ ditolak. Meskipus demikian pembelajaran dengan pendekatan RME dapat diterapkan pada siswa yang memiliki self efficacy tinggi maupun siswa yang memiliki self efficacy rendah untuk meningkatkan kemampuan pemecahan masalah matematis siswa karena siswa yang memiliki self efficacy tinggi atau rendah dipengaruhi oleh faktor yang berbeda-beda.Hal ini dapat dilihat pada gambar 2 di bawah ini.

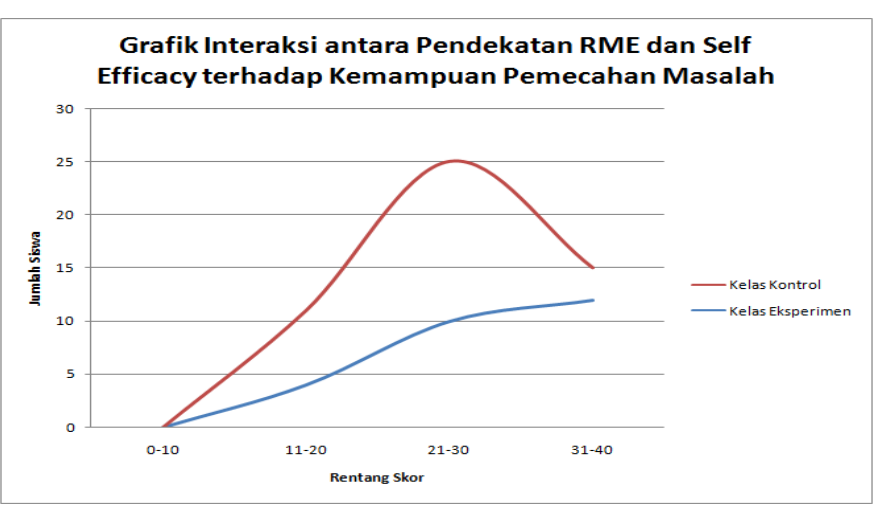

Gambar 2. Grafik Interaksi antara pendekatan realistic mathematics education dan self efficacy terhadap Kemampuan pemecahan masalah matematis

Pada gambar 2 di atas, dapat dilihat bahwa pendekatan dalam pembelajaran dan self efficacy siswa tidak saling berpotongan sehingga model pembelajaran dan self efficacy siswa cenderung tidak ada interaksi diantara keduanya. Hal ini sesuai dengan pernyataan Budiyono (2009) menjelaskan bahwa ada atau tidak adanya interaksi dapat diduga dari grafik profil variabel bebasnya. Jika profil variabel bebas pertama dan kedua tidak berpotongan maka cenderung tidak ada interaksi diantara kedua variabel tersebut.

Hasil pengujian hipotesis melalui uji korelasi roduk moment yang menunjukkan bahwa terdapat hubungan antara self efficacy dengan kemampuan pemecahan masalah matematis siswa dengan $r_{x y}=0.367, t_{\text {hitung }}>t_{\text {tabel }}=2,7655>1,676$. Hal ini terjadi karena proses self efficacy yang diberikan, seperti yang diungkapkan oleh Bunga \& Kiling (2015:36) yaitu proses kognitif (Cognitive Processes), proses motivasi (Motivational Processes), proses afeksi (Affective Processes), dan proses seleksi (Selection Processes).

Pemikiran memberikan arahan bagi tindakan yang dilakukan manusia. Keyakinan seseorang akan efikasi diri mempengaruhi bagaimana seseorang menafsirkan situasi lingkungan, antisipasi yang akan diambil dan perencanaan yang akan dikonstruk. Self-efficacy memainkan peran kunci dalam pengaturan motivasi diri. Sebagian besar motivasi manusia dihasilkan oleh kognitifnya. Orang-orang memotivasi diri dan membimbing tindakan mereka melalui latihan pemikiran. Self-efficacy mempengaruhi seberapa banyak tekanan yang dialami ketika menghadapi suatu tugas. Orang yang percaya bahwa dirinya dapat mengatasi situasi akan merasa tenang dan tidak cemas. Keyakinan terhadap efikasi diri berperan dalam rangka menentukan tindakan dan lingkungan yang akan dipilih individu untuk menghadapi suatu tugas tertentu. Pilihan (selection) dipengaruhi eleh keyakinan seseorang akan kemampuannya (efficacy)

\section{SIMPULAN}

Berdasarkan penelitian yang telah dilakukan, maka dapat dismpulkan bahwa terdapat perbedaan kemampuan pemecahan masalah matematis siswa yang diajarkan menggunakan pendekatan Realistic Mathematics Education (RME) dengan pendekatan konvensional pada siswa kelas IV SD 22 Andalas Padang, idak terdapat perbedaan kemampuan pemecahan masalah matematis siswa yang memiliki self efficacy tinggi dengan siswa yang memiliki self efficacy rendah pada siswa kelas IV SD 22 Andalas Padang, tidak terdapat interaksi antara self efficacy dan pendekatan Realistic Mathematics Education (RME) dalam mempengaruhi 
2008 Pengaruh pendekatan RME dan Self Efficacy terhadap kemampuan pemecahan masalah matematis siswa di sekolah dasar-Oktaveni Yetri, Ahmad Fauzan, Desyandri, Yanti Fitria, Farida Fahrudin

kemampuan pemecahan masalah matematis siswa Ar-Raniry Banda Aceh, 3(2), 92-101.

kelas IV SD Negeri 22 Andalas, dan terdapat hubungan antara self efficacy dengan kemampuan pemecahan masalah matematis siswa

\section{DAFTAR PUSTAKA}

Bunga, B. N., \& Kiling, I. T. (2015). Efikasi Diri dan Pengukurannya pada Orang Usia Lanjut. Jurnal Researchgate. Seminar Nasional Educational Wellbeing. Universitas Nusa Cendana, (2009), 33-43.

Djam'an, N. (2014). Application of the Realistic Mathematics Education (RME) Approach with a Focus on Social Justice in Teaching and Learning Mathematics. Curtin University.

Fauzan, A. (2013). Pengaruh Pendekatan RME dan Kemandirian Belajar Terhadap Kemamampuan Matematis Siswa. Prosiding Semirata FMIPA Universitas Lampung, 7-14

Fauzan, A., \& Sari, O. Y. (2017). Pengembangan Alur Belajar Pecahan Berbasis Realistic Mathematics Education. Prosiding Seminar Nasional Pascasarjana Unsyiah. Aceh, 5563.

Fitriani, K., \& Maulana, -. (2016). Meningkatkan Kemampuan Pemahaman Dan Pemecahan Masalah Matematis Siswa Sd Kelas V Melalui Pendekatan Matematika Realistik. Mimbar Sekolah Dasar, 3(1), 40-52. https://doi.org/10.17509/mimbarsd.v3i1.2355

Pangastuti, S. (2014). Meningkatkan Prestasi Belajar Matematika Menggunakan Pendekatan Realistic Mathematics Education (RME) Di Kelas IV SD Negeri 66/Iv Kota Jambi, 1-12.

Rosyida, Fatiya; Utaya, S. B. (2016). Pengaruh Kebiasaan Belajar Dan Self-Efficacy Terhadap Hasil Belajar Geografi Di SMA. Jurnal Pendidikan Geografi:. Universitas Malang, 89-100.

Setyaningsih, S. (2015). Pengembangan Soal Matematika Model PISA Pada Konten Uncertainty and Data Untuk Mengukur Kemampuan Penalaran Siswa. Journal Pendidikan Matematika. Universitas Muhammadiyah Surakarta.

Susanti. (2017). Meningkatkan Kemampuan Pemecahan Masalah Matematis dan SelfEfficacy Siswa MTs Melalui Pendekatan Pendidikan Matematika Realistik. Journal of Mathematics Education. Universitas Islam 